\title{
Using of Tillandsia usneoides L. as Dust Biomonitor around Natural Gas Separation Factory
}

\author{
Naruephon Duanchan ${ }^{1}$, Natthaya C. van Beem ${ }^{2}$, and Kua-anan Techato ${ }^{1 *}$
}

\begin{abstract}
Tillandsia usneoides L. plant or Spanish moss was used as dust biomonitor. This study was taken place around the area of natural gas separation factory in Songkhla, Thailand. The analysis had also investigated the size of dust during May to June 2014 which is raining and during February to March 2015 which is summer season by collecting data once a month. The quantity of TSP should be compared to the result from monitoring by the process of Post Environmental Impact Assessment (EIA) of gas separation factory. The result of the first month or May to June 2014 showed that the mean amount of TSP on plant was $25 \%(\mu \mathrm{g} / \mathrm{ml})$, $33 \%(\mu \mathrm{g} / \mathrm{ml})$ and result of February to March 2015 showed that the mean amount of TSP $38 \%(\mu \mathrm{g} / \mathrm{ml}), 62 \%(\mu \mathrm{g} / \mathrm{ml})$ related to all particles on the Tillandsia usneoides L.
\end{abstract}

Keywords - Tillandsia usneoides L., Biomonitor, and TSP.

\section{INTRODUCTION}

$\mathrm{T}$ $\mathrm{HE}$ air pollution problem is occurred from various industries. One of the important industries is the gas separation plant in Songkla, Thailand. Because of a part of energy industries in Thailand, it is monitored seriously by the post Environmental Impact Assessment. The air pollution measurement regulation is commonly measured within certain hours, days, or weeks. The real operation is however going on for the whole year. The double check of the dust problem by using plant would be one of the save solution compared to the measurement by equipment. There are many kinds of plant used in the monitoring of dust. For this study the Tillandsia usneoides L. is used because the plant is epiphyte, xerophyte, and growth retardant which is easy for growing (without soil, no need watering, and no need fertilizing).

\section{METHODS}

The Spanish moss were planted and cleaned with DI water. The plants were brought to the four corners of the gas separation factory. Each corner was placed with 3 sets of the Spanish moss. Each set was controlled the weight at $25 \mathrm{~g}$. The distance between set was around $3 \mathrm{~m}$. The duration of experiment was two months in summer and another two months in raining season. After growing plant as the aforementioned time, the samples were brought to the

\footnotetext{
${ }^{1}$ Faculty of Environmental Management, Prince of Songkla University, Hatyai Songkhla, Thailand

${ }^{2}$ Faculty of Science, Thaksin University, Paphayom Phatthalung, Thailand.
}

laboratory. The dust on the Spanish moss was removed by the water and analyzed by the LS Particle Size Analyzer and also filtered to find out the total weight of the dust.

\section{RESULT AND DISCUSSION}

The average of TSP in May and June 2015 in raining season is $25 \%(\mu \mathrm{g} / \mathrm{ml})$ and $33 \%(\mu \mathrm{g} / \mathrm{ml})$. The average of TSP in February and March 2015 in summer season is 38\% $(\mu \mathrm{g} / \mathrm{ml})$ and $62 \%(\mu \mathrm{g} / \mathrm{ml})$ as shown in Figure 1.

The TSP on the Spanish moss in summer is higher than the raining season because of the dust leaching by the rain.

In summer the dust could be blown easily compared to raining season which has high humidity in the air causing the high size from combining of particle.

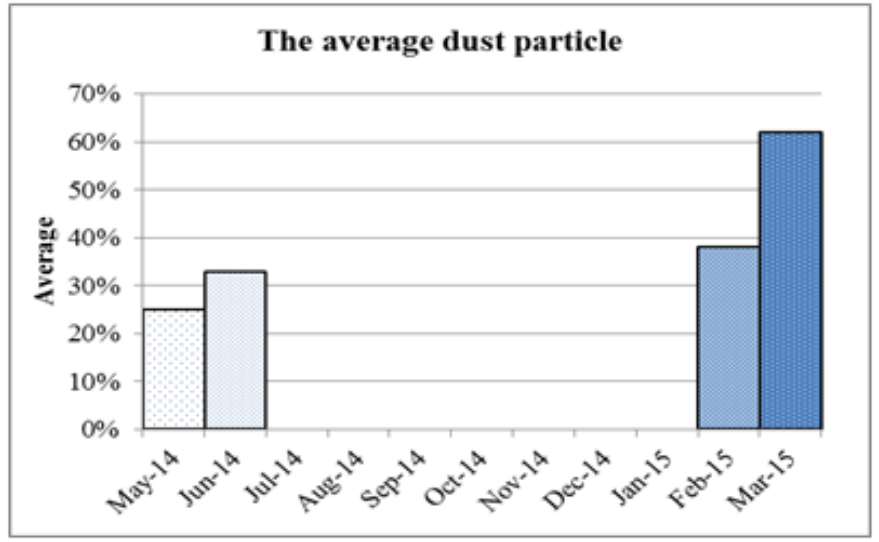

Fig. 1: The average dust particle in summer and raining season

\section{CONCLUSION}

From using the Spanish moss as dust biomonitor around the gas separation plant in Songkhla, Thailand, the amount of dust in summer is higher than the raining season. This research cannot be concluded now as the amount of dust found on the Spanish moss during the experiment had not been compared the standard measurement of the dust in the experimental area.

\section{ACKNOWLEDGMENT}

With thank you for Trans Thai-Malaysia (Thailand) Limited, Dr, Teerawet Titseesang from KMITLB, and Research and Researcher for Industry (RRI). 


\section{REFERENCES}

[1] A.J. Fernandez, M. Ternero, F.J. Barragan, and J.C, Jimenez. "An approach to characterization of sources of urban airborne particles through heavy metal speciation." Chemosphere. 2000. 2:123-136. http://dx.doi.org/10.1016/s1465-9972(00)00002-7

[2] D.A Grantza, J.H.B. Garnerb. and D.W. Johnson. "Ecological effects of PM.” Environmental International. 2003. 29:213-239. http://dx.doi.org/10.1016/S0160-4120(02)00181-2

[3] R. Haslam, A. Borland, K. Maxwell, and H. Griffiths. "Physiological responses of the CAM epiphyte Tillandsia usneoides L. (Bromeliaceae) to variations in light and water supply." Journal of Plant Physiology. 2003. 160: 627-634. http://dx.doi.org/10.1078/0176-1617-00970

[4] G.J Husk. "Spatio-temporal Dynamics of Spanish Moss (Tillandsia usneoides L.; Bromeliaceae) Biogeochemistry." M.S. Thesis. University of Central Florida, Orlando, FL, USA. 1999.

[5] A. Papini, G. Tani, P.D. Falco, and L. Brighigna. "The ultrastructure of the development of Tillandsia (Bromeliaceae) trichome." Flora. 2010. 205: 94-100.

http://dx.doi.org/10.1016/j.flora.2009.02.001 